Journal

of Geography,

Politics and Society

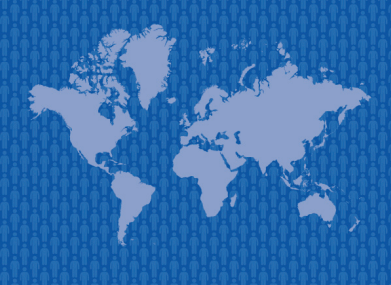

$10(4) / 2020$

\section{Journal of Geography, Politics and Society}

2020, 10(4), 17-22

https://doi.org/10.26881/jpgs.2020.4.03

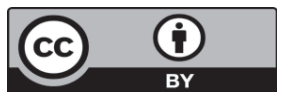

\title{
THE ROLE OF MICRO-ENTERPRISES IN SHAPING THE SOCIAL SECURITY OF THE STATE. A THEORETICAL ANALYSIS
}

\author{
Danuta Plecka (1), Agnieszka Wlazły (2) \\ (1) Department of Administration, Higher School of Management Personnel, Zagórowska 3a, 62-500 Konin, Poland, ORCID: 0000-0002-8504-279X \\ e-mail: danakar1@wp.pl (corresponding author) \\ (2) Department of Economic and Technical Sciences, State Higher Vocational School in Konin, Przyjaźni 1, 62-500 Konin, Poland, ORCID: 0000-0002-7370-3554 \\ e-mail: kancelaria@abakusplus.com.pl
}

\section{Citation}

Plecka D., Wlazły A., 2020, The Role of Micro-enterprises in Shaping the Social Security of the State. A Theoretical Analysis, Journal of Geography, Politics and Society, 10(4), 17-22.

\begin{abstract}
The article presents considerations regarding the functioning of micro enterprises on the market and their impact on the social security of the state. The concept of micro enterprise and social security has been explained in detail. Social security threats and the role of micro sector companies in shaping this area of state security were also discussed. The considerations highlighted the importance of small business in creating conditions for economic stability and development guarantees for local communities.
\end{abstract}

\section{Key words}

micro enterprises, social security, social threats, local community.

\section{Introduction}

Security is one of the basic needs of man and society. It is assumed that its implementation depends on three factors: the state as the creator of social security, the community shaping social capital and the individual taking care of the development of human capital. It is difficult to define clearly which of them is the most important, because the success of social security depends on each of them. These elements also determine the quality of micro-enterprises and, at the same time, success in shaping social security. The aim of the article is to analyse the theoretical relationship between the development of micro-enterprises in the state and stabilization of social security.

In order to understand the concept of security, we must consider its two basic assumptions: survival and development. The first of them clearly refers to the ability to survive physically. This relates not only to the state's military potential, but also, more importantly, to its capabilities in the field of welfare activity (e.g. the quality of and access to healthcare, "contribution" to the demographic development of the society, ageing processes or migrations). Thus, looking from this perspective, security is defined as the product of certain values and goals which determine it, such as: the security of existence, satisfying 
basic needs, protection against the loss of livelihood, balance, and a sense of well-being and satisfaction. As may be noted, the presence and tasks of the state in this respect are essential, because, in today's world, they guarantee that the other assumption of security, i.e. development, will be met. It may obviously be interpreted from the angle of individual development, but it would be quite limited then. There is a type of feedback here: if an individual does not develop, the society does not develop either; if the society does not develop, its members are not likely to develop either. Therefore, when talking about security, it should be pointed out that it provides an objective guarantee of inviolable survival and development (Ferguson, 2018).

Security defined in this way does not exist in vacuum - it must relate to the concepts of different social sciences and humanities. Without drawing on the past experience, one cannot shape its relations with neighbours, i.e. security in the international context. Without knowing social behaviours and political mechanisms, it is difficult to shape the feeling of safety and form the best possible political system, i.e. the one that will ensure survival and the highest degree of development for both individuals and communities. Naturally, development is related to economy. Finally, military potential is inseparably linked with the knowledge of the rules of physics and chemistry (Dean, 2019).

These few examples are sufficient to show how high potential of interdisciplinarity security has as a scientific field. Social security is one of its platforms and has become a significant part of the discourse on the quality of life of individuals and social groups. It encompasses all legal and organisational efforts undertaken by the authorities both in the national and international dimension which "are aimed at ensuring a proper living standard for people, families and social groups and preventing them from being marginalised and socially excluded" (Leszczyński, 2011, p. 22). It would be oversimplification though if we considered governments to be the only bodies responsible for action in this respect. Also citizens play a very important role in shaping social security. Therefore, if the established social goals are to be achieved, responsibility must be shared between the authorities and the society. Otherwise, people acquire a sense of helplessness and fall into the habit of expecting others to solve their problems; thus, they gradually lose the ability to cope with hardships, such as the loss of job, natural disasters, etc. At the same time, "learned helplessness" may lead to abusing the state's help and, consequently, to its withdrawal from the sphere of pro-social activities (Marszałek-Kawa et al., 2018).
In the literature on internal and national security (Leszczyński, 2011; Plecka, Rutkowska, 2016), the social dimension of security is often narrowed down to welfare issues and the state's tasks related to them. Thus, a number of important aspects of social security are ignored. Among them, one of the most vital areas is the problem of development, i.e. human capital, which involves people's qualifications, knowledge, skills, etc. Another important aspect refers to the dimension of societal security, seen mostly in the context of social capital and the related culture of social trust, citizens' participation and other elements, such as the ability to cooperate in crisis situations or the development of civil society. This does not mean that problems located in the traditional sphere of welfare security do not concern its social dimension. However, it must be emphasised that they are only one of the components of social security and, as important as they are, they are only a supplement to its developmental and community dimensions (Leszczyński, 2011).

It seems justified to say that it is not possible to effectively introduce welfare security without developmental elements, such as human capital. This capital has low shaping potential if the society is devoid of the dimension of societal security whose the integral component is social capital. Such a phenomenon is relatively new in the debate on citizens' security in the political system. It is connected with various aspects, the most important of which seems to be the increasing number of social threats that negatively affect both the consolidation of democracy and citizens' development prospects. At the same time, it may be noted that the category of social security has supplanted the term social policy in the awareness of both politicians and individual (Stiglitz, 2015; Piketty, 2015). Moreover, both concepts are often seen as synonyms in public space. The categories of social security and welfare security are perceived as equivalent concepts even more frequently. It is obviously inconsistent with the characteristics and definitions of the phenomena, and they should not be considered to be synonyms, but as separate concepts. Social security involves a wide array of activities performed by different entities, while welfare security refers to the state's activity in the sphere of welfare policy only.

While M. Leszczyński's definition (Leszczyński, 2011) of the category of social security that we adopted in this paper comprehensively focuses on the issue of the diagnosis of threats and possible solutions to problems - through the state's intervention and social or developmental capital, the concept of welfare security or welfare policy refers only to the state's role in ensuring social security. Thus, 
these phenomena address the problem in a small segment of activities which are necessary for a citizen to function properly in the society. Therefore, it may even be stated that it is one of the pillars of social security, which is obviously essential, but not the only one. It has formal instruments and is managed by state institutions. However, without the participation of the community and individuals, in the long-term, they may become inefficient when it comes to efforts undertaken for the sake of social security. Not only do the consequences affect the state budget, but they also (or perhaps first of all) influence individuals, who become clients rather than citizens: people dependent on aid institutions instead of being the creators of their own life. This is why it is so important to implement and use the pillars of social security in the welfare, community and developmental dimension. Otherwise, social security will be narrowed down to the issue of social engineering, which focuses on the technical solution to a specific social problem instead of shaping the feeling of safety in the community. Thus, it may largely contribute to the reinforcement of the habit of expecting others to solve their problems and the attitude of "learned helplessness". This leads to the increased activity of the state as the only participant of social security. Thus, it may significantly contribute to the strengthening of a demanding attitude or "learned helplessness". It leads to the intensification of the state's efforts as the only participant of social security. The state's activity aimed at stimulating the development of micro-enterprises is one of the forms of preventing or combating demanding attitudes among citizens.

\section{The essence of micro-enterprises}

Enterprises, just like households, constitute the main entities of the state's economic sphere. An economist, A. Krajewska (2018), defines an enterprise as a set of people and material and cash resources, established with an aim of running a specific business activity and distinguished from the technical-service, legal, technical-production, economic, spatial and organizational perspectives.

The essence of the existence of enterprises lies in business activity, based on the principles of economy, i.e., seeking the return on investment and profit. From the point of view of economic sciences, running one's own business concerns any human activity, undertaken with an intention to adapt one's resources, means and surrounding, to produce new goods or transform the products already made, separate and consume them (Stachowiak, 1998). In economic terms, an enterprise thus focuses on manufacturing processes and the division of goods.

When analysing the issue of an enterprise from the economic perspective, many different types of business entities are distinguished. They are organised in different ways, but the economic orientation of their activity is the same (Vetrivel, 2017).

Taking the above into consideration, an enterprise has the following characteristics (Nasiłowski, 2016): unchangeable, clear roles arising from the analysis of the environment and the company's strengths and weaknesses, and from its position in the market surrounding; its activity is targeted at fulfilling consumers' needs in return for money and obtaining economic surplus; it has financial resources; it makes independent decisions under the legal and economic conditions of a given country; it operates in the market at its own risk, often within the scope of CSR (Corporate Social Responsibility); its actions should be marked with continuity and invariability.

What distinguishes enterprises from other entities functioning in the market surrounding is seeking a profit as the main priority, maintaining a top market position, and the pursuit of constant development. A business entity which hinders its own development in a dynamic ever-changing environment will definitely collapse (Białoń, 2019).

Micro-enterprises have a significant influence on the condition of national economies today. They also contribute to the acceleration of the pace of economic growth of a given region. They positively affect the mobilisation of human resources by encouraging people to seek employment in a local labour market as a result of which the unemployment rate decreases. What is more, they offer professional services targeted at the inhabitants of a specific area and introduce goods and services into the local market (Czajkowska, 2013).

Micro-enterprises are usually considered on an equal footing with an enterprise as they may also be connected with the factories that are its components. Due to their strong link with and influence on the local environment, enterprises are considered as the stimulators of regional growth. Therefore, the establishment and growth of modern and competitive companies and the promotion of entrepreneurial culture is one of the most important spheres of the state's "interference" with the local policy of economic development. The state authorities and self-government units often participate in the development of the micro-enterprise sector. Micro-companies are inclined to run business operations within the territory of the region, but they are also able to cooperate with local self-government and other entities in the region. Through the spatial decentralization 
of micro-enterprises, this branch of economy also strongly contributes to the improvement in ecological conditions (Strużycki, 2004).

Micro-enterprises are usually founded in the place of residence of their owners, who fulfil their tax obligations there, take advantage of local resources, and create favourable conditions to investment. Micro-companies adapt to market demands in the quickest possible time and without any major difficulties. They increase the competitiveness of the economic sphere and stimulate economic development (Czajkowska, 2013).

The existing body of literature in the fields of law, economy and management provides a number of different measures to classify business entities according to their size. N. Daszkiewicz and K. Wach (2013) indicate that the concepts of micro-, small or medium enterprises are differently defined across countries, mainly because of differences in the pace of economic growth. Experts emphasise that the division of companies into micro-, small, medium and big enterprises is determined by the economic development strategy of a given country. In order to classify business entities, both quantitative and qualitative indicators can be used.

Qualitative variables present the condition or position of a firm in a specific industry. T. Łuczka (2001) introduced the following division of qualitative criteria: the owner-entrepreneur's legal autonomy; the owner's relevant function, according to the principle of personal management; the traditional organizational structure of a company; separate financial management and sources of financing.

Other qualitative indicators used for describing the sector of micro-, small and medium enterprises are, among others: effectiveness, productivity, innovativeness, creativity, combination, predictive ability and the strength of influence upon the environment. These criteria are based on the level of knowledge of the market, the owners' network of contacts and influences, and their ability to adapt and establish close, long-term relations with customers (Czajkowska, 2013).
In general, a few, easily measurable qualitative indicators, based on widely available statistical data, are applied. They include (Łuczka, 2001): the number of employees, the amount of sales (annual turnover), the value of assets (assets versus liabilities, i.e., the balance-sheet total), the level of annual income ( $\mathrm{mi}$ nus tax and insurance), the average bank account balance, and the length of time on the market.

In January 2005, under the new law regulations arising from Poland's accession to the European Union, a new type of business entities - micro-enterprises, employing no more than 10 people - was introduced. Companies belonging to this category have the following characteristics: they have a uniform business profile, they operate in one sphere of business activity, usually focusing on commerce, services, building, transportation or real estate market (Czajkowska, 2013).

Under the Act - Entrepreneur law (Journal of Laws of 2018, item 646 as amended, art. 7, par. 1, p. 1) (Ustawa..., 20218), a micro-entrepreneur is a trader who in one of the last two fiscal years has employed no more than 10 employees and his net turnover from sale of goods, services or financial operations does not exceed the PLN equivalent of $€ 2,000,000$ or if assets at the end of either fiscal year do not exceed the above amount.

The fact whether a given entity is classified as a micro-, small or medium company is not determined by its legal form - no matter whether it is a natural person, a legal entity or an entity with no legal personality, but holding full legal capacity. However, natural persons conducting business activity prevail among micro-enterprises (Horosz, Antoniuk, 2009).

Table 1 presents a new typology of business entities divided into micro-, small and medium enterprises, as established by the European Commission. Bearing in mind the European Union's demand for statistical data, in the annual reports prepared by EU member states, various types of studies take into account only the quantitative criterion - the size of employment on the basis of which the following

Tab. 1. The division of business entities in the European Union into micro-, small and medium-sized enterprises

\begin{tabular}{|c|c|c|c|c|c|}
\hline \multirow{2}{*}{ Type of enterprise } & \multirow{2}{*}{$\begin{array}{c}\text { Employment } \\
\text { size }\end{array}$} & \multicolumn{3}{|c|}{ 1996-2004 } & \multicolumn{2}{c|}{ 2005-to present } \\
\cline { 3 - 6 } & & \multicolumn{4}{|c|}{ Maximum amount (in million euro) } \\
\cline { 3 - 6 } & & Balance & Revenue & Balance & Revenue \\
\hline Micro- & max 9 & Lack of adopted definition & 2 & 10 \\
\hline Small & $10-49$ & 5 & 7 & 43 & 10 \\
\hline Medium-sized & $50-249$ & 27 & 40 & 50 \\
\hline
\end{tabular}

Source: Commission Recommendation of 6 May 2003 concerning the definition of micro-, small and medium-sized enterprises, Recommendation 03/361/EC. Official Journal L124 of 20 May 2003; Act of 6 March 2018 - Entrepreneur law (Entrepreneur law (Journal of Laws of 2018, item 646 as amended, art. 7, par. 1, p. 1-3) (Ustawa..., 2018). 
entities can be distinguished (Daszkiewicz, Wach, 2013): self-employed people (no employed workers irrespective of the type of contract); micro-enterprises (no more than nine employees); small enterprises (from 10 to 49 employees); medium-sized enterprises (from 50 to 249 employees); big enterprises (from 250 employees).

\section{The role of micro-enterprises in counteracting threats to social security}

The visible role of micro-enterprises mainly stems from the fact that they constitute the dominant group among all economic entities and that they have a substantial share in the creation of new, different - in terms of education and abilities - workplaces (especially for the community of a given region). A favourable situation in the sphere of micro-, small and medium-sized companied affects both the local-regional development and the cohesiveness of the society (Szramowski, 2018).

The strength of the sector of micro-enterprises is the fact that it creates the biggest number of jobs, more than big corporations. Micro-companies dominate when it comes to the use of local material resources, raw materials and staff, which makes them an effective tool for fighting unemployment in small cities and towns. The lack of industrial production in such areas contributes to an increase in the unemployment rate; therefore, micro-enterprises also play a key role in combating unemployment in the local community. For many jobless people, such companies are an ideal solution because of their dynamic operations in the market and flexibility in adapting to the constantly changing environment (Nowak, Szałański, 2013).

Entrepreneurial activities in the sphere of enterprises are created by an individual and his or her relations with other people, and with the environment. Although entrepreneurship has a social and economic aspect, it is mainly reflected in the context of a given business entity and in the actions of people working there. The success of individuals translates into the success of the whole community (Koźmiński, 2005).

In the economic and social surrounding, microenterprises also play an essential role at the regional level from the perspective of: technological progress, the creation of new workplaces, the minimization of harmful influence on the natural environment, the intensification of the manufacturing process on a local scale, effective crisis management in times of an economic slump, recession or crunch, no special requirements concerning the location, the effect of the mobilisation of financial resources, and the transformation effect (Dominiak, 2005).

To conclude, the role of micro-enterprises in shaping social security consists in: creating additional, mainly specialised, modern workplaces by way of setting up one's own business or recruiting employees; participating in the generation of gross domestic product and regional income by contributing to the creation of favourable events or increasing the efficiency of the existing business spheres (the socalled multiplier effect); an effective use of regional resources, e.g. raw materials, human resources, infrastructural background, landscape or culture. What is important for the shaping and improving social attitudes, micro-companies show a high degree of independence in coping with problems arising and satisfy their needs by acting rather than waiting for institutional aid. As regards the social pillar of security, micro-enterprises initiate and implement investment projects to serve the inhabitants of a given region and they can quickly adapt to the changing market circumstances. From the local perspective, they often become instruments for initiating changes in the sphere of innovation, mainly owing to the accumulation and use of the available intellectual, economic, material, financial and social resources of regional economy. They also participate in dedicated programmes, use grants and subsidies promoting the development of human resources, financed both form public and private sources, and minimise the effects of disturbances in economic stability.

All these factors make micro-enterprises become a component of two pillars of social security: developmental and community security. Thus, they unburden the state when it comes to social security. Owing to this, with properly conducted welfare policy, the state can be more effective in the social sphere, and the aid goes directly to those in who need it the most.

\section{Conclusions}

There is a feedback loop between all three elements of social security: social, community and development security and the success of micro-enterprises in the country: on the one hand, micro-enterprises largely contribute to the development of social security; on the other hand, the development of individual economic competences, the culture of social trust, which are necessary to talk about community and social capital. Finally, the legal and fiscal stimulation of the state allows for the efficient functioning of micro-enterprises. 


\section{References}

Baruk J., 2002, Dylematy rozwoju małych i średnich przedsiębiorstw (Eng. Dilemmas in the development of small and medium-sized enterprises), Gospodarka Narodowa, 3, 12-25. doi: 10.33119/GN/113829

Białoń L., 2019, Przedsiębiorstwo (Eng. Entrepreneurship), [in:] S. Marciniak (eds.), Makro- i mikroekonomia. Podstawowe problemy współczesności (Eng. Macro and microeconomics. Basic problems of the present day), Wydawnictwo Naukowe PWN, Warszawa, 124-167.

Commission Recommendation of 6 May 2003 concerning the definition of micro-, small and medium - sized enterprises, Recommendation 03/361/EC. Official Journal L124 of 20 May 2003, https://eur-lex.europa.eu/legal-content/EN/ TXT/HTML/?uri=CELEX:32003H0361\&from=FR (accessed 15 May 2020).

Czajkowska A., 2013, Kredytowanie przedsiębiorców indywidualnych - specyfika, procesy, polityka, (Eng. Lending to individual entrepreneurs - specificity, processes, policy), Wydawnictwo Uniwersytetu Łódzkiego, Łódź.

Daszkiewicz N., Wach K., 2013, Małe i średnie przedsiębiorstwa na rynkach międzynarodowych, (Eng. Small and medium-sized enterprises in international markets), Wydawnictwo Uniwersytetu Ekonomicznego w Krakowie, Kraków.

Dean H., 2019, Social Policy, Policy Press, Bristol.

Dominiak P., 2005, Sektor MSP we współczesnej gospodarce (Eng. The MSP sector in the modern economy), Wydawnictwo Naukowe PWN, Warszawa.

Ferguson I., 2018, Global Social work and political context, Policy Press, Bristol.

Horosz P., Antoniuk J.R., 2009, Prawne podstawy przedsiębiorczości (Eng. Legal basis of entrepreneurship), Wydawnictwo Wolters Kluwer, Warszawa.

Koźmiński A., 2005, Zarzq̨dzanie w warunkach niepewności (Eng. Management under uncertainty), Wydawnictwo Naukowe PWN, Warszawa.

Krajewska A., 2018, Produkcja i koszty w przedsiębiorstwie (Eng. Production and costs in the enterprise), [in:] R. Milewski, E. Kwiatkowski (eds.), Podstawy ekonomii (Eng. Basics of economics), Wydawnictwo Naukowe PWN, Warszawa, 24-48.

Leszczyński M., 2011, Bezpieczeństwo społeczne Polaków wobec wyzwań XXI w. (Eng. Social security of Poles in the face of the challenges of the 21st century), Wydawnictwo Difin, Warszawa.

Łuczka T., 2001, Kapitał obcy w małym i średnim przedsiębiorstwie (Eng. Foreign capital in small and medium-sized enterprises), Wydawnictwo Naukowe PWN, Warszawa-Poznań.

Marszałek-Kawa J., Plecka D., Hołub A., 2018, Social Security. Selected Aspect, Wydawnictwo Adam Marszałek, Toruń.

Nasiłowski M., 2016, System rynkowy. Podstawy mikro-i makroekonomii (Eng. Basics of micro- and macroeconomics), Wydawnictwo KeyText, Warszawa.

Nowak A.Z., Szałański M., 2013, Mikrofirmy siłą napędowa gospodarki Mazowsza (Eng. Micro-enterprises as a driving force of Mazovia's economy), Wydawnictwo Naukowe Wydziału Zarządzania UW, Warszawa.
Piketty T., 2015, Ekonomia nierówności (Eng. The Economics of Inequalities), Wydawnictwo Krytyki Politycznej, Warszawa.

Plecka D., Rutkowska P., 2016, Societal security as an instrument for creating populist attitudes, Political Preferences, 13, 45-61. doi: 10.6084/m9.figshare.4284650

Stachowiak Z., 1998, Ekonomia. Zarys podstawowych problemów (Eng. Outline of the basic problems), Wydawnictwo Wyższej Szkoły Informatyki Stosowanej i Zarządzania, Warszawa.

Stiglitz J.E., 2015, Cena nierówności. W jaki sposób dzisiejsze podziały społeczne zagrażaja naszej przyszłości (Eng. The price of inequality. How today's social divisions threaten our future),Wydawnictwo Krytyki Politycznej, Warszawa.

Strużycki M., 2004, Małe i średnie przedsiębiorstwa w gospodarce regionu (Eng. Small and medium-sized enterprises in the economy of the region), Polskie Wydawnictwo Ekonomiczne, Warszawa.

Szramowski D., 2018, Kapitał ludzki w mikro i małych przedsiębiorstwach (Eng. Human capital in micro and small enterprises), Wydawnictwo CeDeWu, Warszawa.

Ustawa z dnia 6 marca 2018 r. - Prawo przedsiębiorców (Eng. Act of 6 March 2018 - Entrepreneur law), 2018 (Dz.U. z 2018 r. poz. 646 z późn. zm.).

Vetrivel, K., 2017, Performance of micro, small and medium enterprise, OmniScriptun GmbH\&Co, Ryga. 